Vol. 24, No. 3, Juli 2021, hlm. 533-544

p-ISSN: 1410-9344; e-ISSN: 2549-5631

WARTA LPM

homepage: http://journals.ums.ac.id/index.php/warta

\title{
Pemberdayaan Karang Taruna Dusun Malasan melalui Produksi Pupuk Organik Cair Asari untuk Subsidi Pupuk kepada Kelompok Tani
}

\author{
${ }^{1}$ Bandiyah Sri Aprillia, ${ }^{2}$ Yossi Safitri dan ${ }^{3}$ Ayu Siti Aminah \\ ${ }^{1,3}$ Teknik Elektro, Fakultas Teknik Elektro, Telkom University \\ ${ }^{2}$ Teknik Industri, Fakultas Rekayasa Industri, Telkom University \\ email: ${ }^{1}$ bandiyah@telkomuniversity.ac.id, ${ }^{2}$ yossisafitri@student.telkomuniversity.ac.id, , ${ }^{3}$ ayayusa@student. \\ telkomuniversity.ac.id
}

\section{Article Info}

Submitted: 13 January 2021

Revised: 12 April 2021

Accepted: 28 June 2021

Published: 20 July 2021

Keywords: POC subsidies, youth organization, liquid organic fertilizer, community empowerment.
Kata kunci: Subsidi POC, Karang Taruna, Pupuk Organik Cair, Pemberdayaan Masyarakat.
Abstract

The Covid-19 pandemic has impacted the people of Malasan Hamlet, Ketitang Village, Juwiring District, Klaten Regency, Central Java. The impact experienced by youth in the area appeared in the form of layoffs by companies. The objective of Innovillage Program is to be a community service program aimed to explore and utilize the potential of Dusun Malasan to improve the standard of living of the village community through empowering youth organizations. The youth organization, which consists of young people in Dusun Malasan accompanied by Telkom University, are trained as peer mentors and disseminators. Youth organizations as peer mentors are responsible for the production and testing of their processed liquid organic fertilizers. Karang Taruna as a disseminator conducts training activities or production workshops and procedures for using liquid organic fertilizers to farmer groups. Karang Taruna also conduct commercialization training to farmer groups. The raw materials to be used are raw materials that are easily found in this area, namely, cow dung and banana trees. Based on the results of testing the POC concentration on the height of rice plants, it was shown that POC spraying with a concentration of $0.6 \%$ was able to increase plant height after 30 days of planting. Meanwhile, spraying $0.4 \%$ and $0.6 \%$ POC on 60-day-old plants showed only a slight difference in height. In addition, giving POC with a concentration of $0.2 \%$ was able to increase the number of tillers at the age of 30 and 60 days. After conducting training on the production and marketing of POC in Karang Taruna, Dusun Malasan, more than $85 \%$ of the members of the Youth Organizations were able to practice the POC production and marketing process.

\footnotetext{
Abstrak

Dampak pandemi Covid-19 khususnya terjadi pada masyarakat Dusun Malasan, Desa Ketitang, Kecamatan Juwiring, Kabupaten Klaten, Jawa Tengah. Dampak pandemi Covid-19 yang dialami oleh pemuda berupa
} 
pemutusanhubungankerja olehperusahaan. Tujuan ProgramInnovilage dengan skema kegiatan pengabdian masyarakat bertujuan menggali dan memanfaatkan potensi Dusun Malasan untuk meningkatkan taraf hidup masyarakat desa melalui pemberdayaan karang taruna. Pihak karang taruna, yang beranggotakan para pemuda pemudi di Dusun Malasan didampingi pihak Universitas Telkom dilatih sebagai mentor sebaya dan desseminator. Karang taruna sebagai mentor sebaya bertanggung jawab atas produksi dan pengujian pupuk organik cair olahannya. Karang taruna sebagai dessiminator melaksanakan kegiatan pelatihan atau workshop produksi dan tata cara penggunaan pupuk organik cair ke kelompok tani. Karang taruna juga melakukan pelatihan komersialisasi produk kepada kelompok tani. Bahan baku yang akan digunakan merupakan bahan baku yang mudah ditemui di daerah ini yaitu kotoran sapi dan pohon pisang. Beradasarkan hasil pengujian konsentrasi POC terhadap tinggi tanaman padi menunjukkan bahwa, penyemprotan POC dengan konsentrasi 0,6\% mampu meningkatkan tinggi tanaman setelah 30 hari tanam. Sedangkan, penyemprotan $0,4 \%$ dan $0,6 \%$ POC pada tanaman berusia 60 hari terlihat hanya sedikit perbedaan tinggi. Selain itu, pemberian POC dengan konsentrasi 0,2 \% mampu meningkatkan jumlah anakan padi pada umur 30 dan 60 hari. Setelah dilakukan pelatihan produksi dan pemasaran POC di Karang taruna, Dusun Malasan lebih dari 85\% anggota karang taruna mampu mempraktikkan proses produksi dan pemasaran POC.

\section{PENDAHULUAN}

Pandemi Covid-19 yang menyebar di Indonesia pada Maret 2020 memberikan dampak ke berbagai daerah dan sektor pencarian. Dampak dari pandemi ini khususnya terjadi pada masyarakat Dusun Malasan, Desa Ketitang, Kecamatan Juwiring, Kabupaten Klaten, Jawa Tengah. Pemuda Dusun Malasan banyak yang merantau ke ibu kota sebagai buruh pabrik, sedangkan masyarakat yang menetap di Dusun Malasan umumnya bekerja sebagai petani. Dampak pandemi Covid-19 yang dialami oleh pemuda berupa pemutusan hubungan kerja oleh perusahaan tempat mereka bekerja. Sebagai contoh nyata, seorang operator crane di Jakarta, berinisial $\mathrm{T}$ dan berumur 32 tahun, mempunyai dua orang anak yang masih di bangku kuliah dan sekolah harus kembali ke kampung halaman karena pemutusan hubungan kerja tersebut. Kasus kedua, seorang pegawai buruh pabrik ternama di Jakarta di rumahkan dengan upah gaji yang masih dibayarkan sebesar 50\%. Kasus ketiga, beberapa remaja yang mengalami pemutusan hubungan kerja tanpa diberikan uang saku. Kasus ketiga merupakan kasus yang paling banyak terjadi pada masyarakat Dusun Malasan. Kasus selanjutnya merupakan dampak nyata pada warga yang bukan perantauan dan merupakan buruh pabrik. Karena berkurangnya konsumen dalam pembeliaan barang mengakibatkan permintaan produksi pada pabrik juga berkurang. Hal ini menyebabkan produksi pabrik berkurang dan berdampak pada pengurangan jumlah buruh. Di Dusun Malasan ini terdapat banyak industri garmen dalam skala menengah ke bawah. Industri tersebut mengalami goncangan yang mengakibatkan pegawai usia remaja mengalami pemutusan hubungan kerja. Kondisi serupa tidak terlalu berdampak dan masih berkelanjutan pada pabrik garmen dalam skala menengah ke atas seperti PT SriTex. Pada kondisi ini beberapa orang yang terdampak pemutusan hubungan kerja beralih menjadi petani, meskipun mereka tidak memiliki sawah.

Buruh tani merupakan mata pencarian utama di Dusun Malasan karena sebagian besar penduduk tidak mempunyai lahan sawah. Pada bidang pertanian ini, terdapat kendala pada ketersediaan pupuk yang digunakan oleh 
para petani. Kondisi lahan di Dusun Malasan cukup luas sehingga membutuhkan banyak pupuk, terutama untuk tanaman padi. Kondisi sebelumnya untuk memenuhi kebutuhan pupuk, petani bebas melakukan pembelian pupuk sesuai dengan kemampuan mereka. Pada saat ini, pupuk yang beredar merupakan pupuk subsidi dari pemerintah. Kebijakan terkait pupuk bersubsidi diatur dalam Peraturan Presiden RI No. 15 Tahun 2011 yang merupakan Perubahan Atas Peraturan Presiden Nomor 77 Tahun 2005 yang menyatakan penetapan Pupuk Bersubsidi sebagai Barang dalam Pengawasan (Viery, Syafridatati, and Deaf 2020). Sistem yang digunakan pemerintah tersebut mewajibkan petani untuk memiliki kartu tani yang nantinya digunakan untuk membeli pupuk. Setiap kartu tani dibatasi pembelian pupuk sebanyak 2 karung per kartu tani. Keadaan tersebut mengakibatkan tidak semua buruh tani di Dusun Malasan memiliki kartu tani, hanya pemilik lahan sawah yang memiliki kartu tersebut. Oleh karena itu, petani tersebut terpaksa meminjam kartu petani ke petani lainnya. Pupuk subsidi pemerintah pun belum cukup untuk memenuhi kebutuhan pupuk petani di Disun Malasan. Hal tersebut disebabkan oleh adanya permasalahan pada pupuk subsidi itu sendiri seperti ketersedian pupuk, harga pupuk yang fluktuatif, serta penggunaan pupuk yang tidak sesuai dosis (Moko, Suwarto, and Utami 2017). Keterbatasan pembelian pupuk dan kelangkaan pupuk membuat petani di Dusun Malasan beralih kepada Pupuk Organik Cair (POC) sebagai alternatif pemenuhan kebutuhan pupuk. Di toko pertanian pada umumnya, POC memiliki harga jual yang cukup tinggi untuk kalangan buruh tani. Berdasarkan permasalahan yang telah dipaparkan dapat disimpulkan bahwa buruh pabrik yang mengalami pemutusan hubungan kerja dan kelangkaan pupuk bagi petani dan buruh tani menjadi permasalahan yang kursial bagi masyarakat di Dusun Malasan. Sehingga perlu dilakukan pembuatan POC secara mandiri oleh masyarakat di Dusun Malasan tersebut demi memenuhi kebutuhan pupuk dan membuka ladang pekerjaan baru bagi buruh pabrik yang mengalami pemutusan hubungan kerja. Pada program PKM jangka pendek ini, pihak Universitas Telkom bertujuan untuk memberikan pelatihan produksi POC kepada kelompok karang taruna sekaligus pelatihan komersialisasi produk, desiminasi proses produksi POC, dan pemberian subsidi POC kepada kelompok tani.

Pembuatan pupuk organik cair dapat memanfaatkan kombinasi limbah pertanian dan peternak (Sirajuddin et al. 2021). Dusun Malasan memiliki potensi yang cukup besar untuk memenuhi bahan pokok pembuatan pupuk tersebut, karena banyak masyarakat yang memelihara sapi dan menanam pohon pisang. Kotoran sapi dan batang pisang nantinya dapat dijadikan sebagai bahan baku pembuatan POC. Untuk mempercepat proses pengomposan dan meningkatkan kualitas pupuk, ditambahkan Effective Microorganisms (EM4) kedalam campuran bahan baku POC (Fabiani et al. 2020). Dalam proses pembuatan pupuk yang berkualitas, dibutuhkan standar kadar $\mathrm{pH}$, dan suhu yang sesuai.

Berdasarkan identifikasi permasalahan melalui wawancara langsung (https://www. youtube.com/watch?v=MiynY8B7 Ngg), kegiatan Innovilage ini menjadi salah satu solusi dari dampak pandemi Covid-19 dengan membuka lapangan pekerjaan bagi pekerja yang mengalamai pemutusan hubungan kerja di Dusun Malasan dan dapat menyediakan pupuk bagi petani dan buruh tani. Bahan baku yang akan digunakan merupakan bahan baku yang mudah ditemui di daerah ini yaitu, kotoran sapi dan pohon pisang. Hasil dari produksi pupuk dibagikan kepada petani Dusun Malasan dan untuk keberlanjutannya, pupuk dijual melalui niaga elektronik.

\section{METODE}

Program pengabdian masyarakat ini dilaksanakan di Dusun Malasan, Klaten, Jawa Tengah. Pada program ini melibatkan dua mitra yakni kelompok tani dan karang taruna. Pihak karang taruna, yang beranggotakan para pemuda pemudi di Dusun Malasan didampingi pihak Universitas Telkom dilatih sebagai mentor sebaya dan desseminator. Karang taruna sebagai mentor sebaya bertanggung jawab atas produksi dan pengujian pupuk organik cair olahannya. Tahapan produksi dan pengujian POC disajikan pada Gambar 1 berikut. 


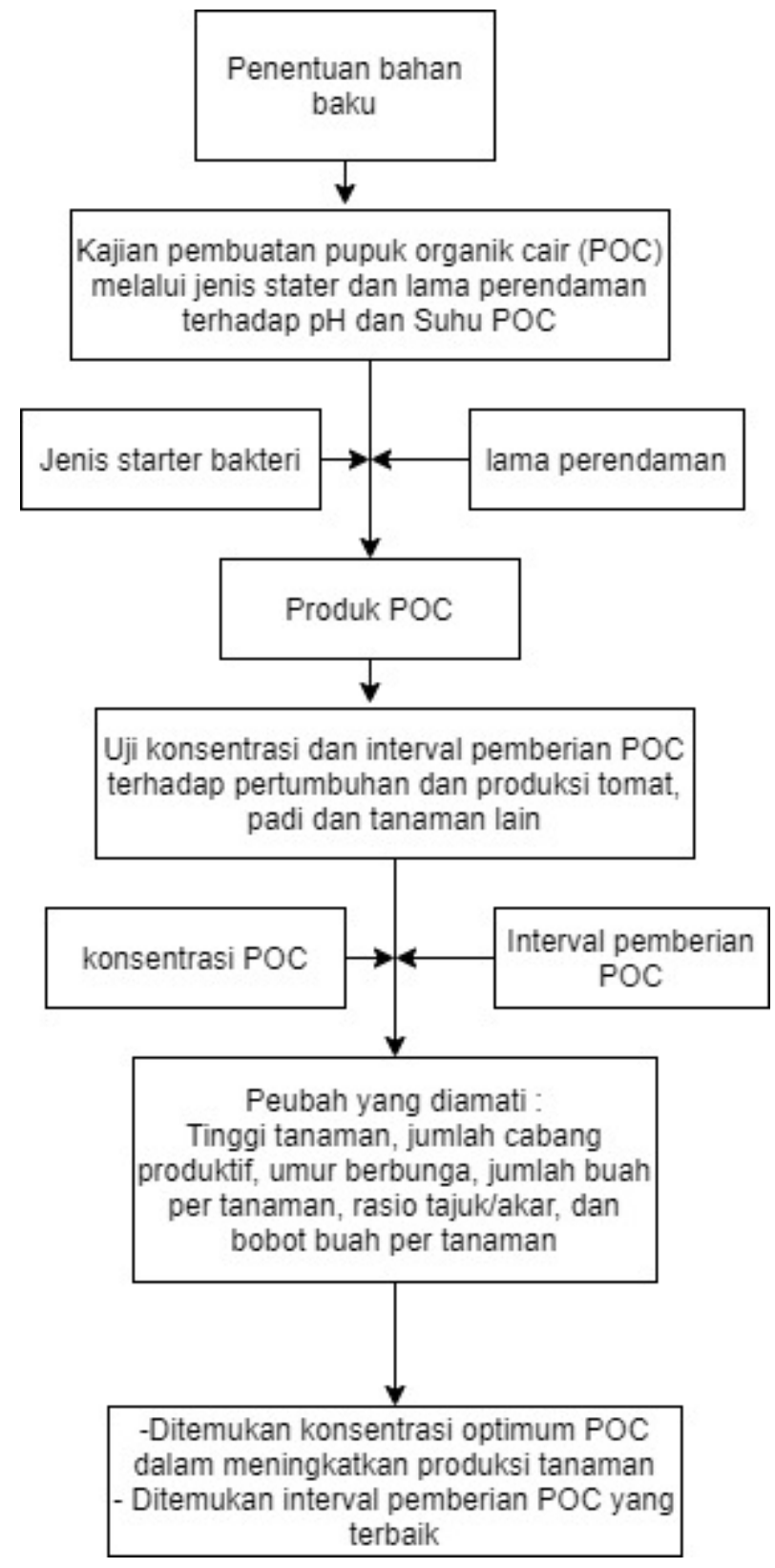

Gambar 1. Tahapan Produksi dan Pengujian POC.

Berdasarkan Gambar 1, tahapan produksi POC meliputi: mengkaji bahan baku yang digunakan dalam pembuatan POC, tata cara pembuatan POC, dan cara pengujian POC sehingga ditemukan konsentrasi yang tepat.

Karang taruna sebagai dessiminator melaksanakan kegiatan pelatihan atau workshop produksi dan tata cara penggunaan pupuk organik cair ke kelompok tani. Karang taruna juga melakukan pelatihan komersialisasi produk kepada kelompok tani. Tahapan pelaksanaan kegiatan secara rinci disajikan pada Gambar 2 .
Pada tahap pelaksanaan kegiatan pembuatan POC dibagi menjadi beberapa tahap yaitu tahap persiapan alat dan bahan, tahap pembuatan POC, dan tahap pengemasan. Proses pelaksanaan tersebut dapat dilihat pada Gambar 2.

Gambar 2, merupakan rincian tahapan pelaksanaan kegiatan pembuatan POC. Tahapan ini dibagi menjadi tiga bagian. Tahapan pertama terdiri dari dua bagian yaitu persiapan alat produksi POC dan persiapan bahan baku POC. Pada persiapan alat pembuatan POC, material yang digunakan adalah drum dengan ukuran 200 liter sebanyak 5 buah beserta tutupnya, keran air, pipa penghubung, gayung, dan ember. Drum, pipa, dan keran air kemudian dirakit menjadi tempat fermentasi POC. Pada persiapan bahan baku pembuatan POC, yang disiapkan berupa kotoran sapi dan pohon pisang yang diambil dari kandang sapi dan kebun pisang warga sekitar Dusun Malasan, EM4 yang diperoleh dari toko, serta air. Sebelum diolah, kotoran sapi terlebih dahulu dikeringkan dengan cara dijemur, lalu untuk pohon pisang di potong menjadi ukuran yang lebih kecil.

Tahapan kedua yaitu memasukkan semua bahan kedalam drum dengan yang berisikan kotoran hewan, potongan pohon pisang, EM4, dan air. Bahan yang telah dimasukkan kedalam drum kemudian diaduk agar tercampur secara merata. Setelah itu, drum ditutup dan dibiarkan selama kurang lebih dua minggu untuk menyelesaikan proses fermentasinya. Selama proses fermentasi dilakukan pengecekan suhu dan pH POC. Jika telah mencapai suhu kamar dan pH 4-6, POC akan memasuki tahap selanjutnya.

Tahapan ketiga adalah pengemasan POC. Sebelum dimasukkan kedalam botol, POC disaring terlebih dahulu untuk memisahkan POC dengan ampas sisa produksi POC. Setelah proses penyaringan selesai, POC dimasukan kedalam botol kemasan dengan ukuran satu liter dan setengah liter. Selanjutnya botol yang telah berisi POC diberi label yang berisi keterangan merek dan cara penggunaan POC tersebut. Biaya produksi POC ASARI secara rinci disajikan pada tabel 1. 


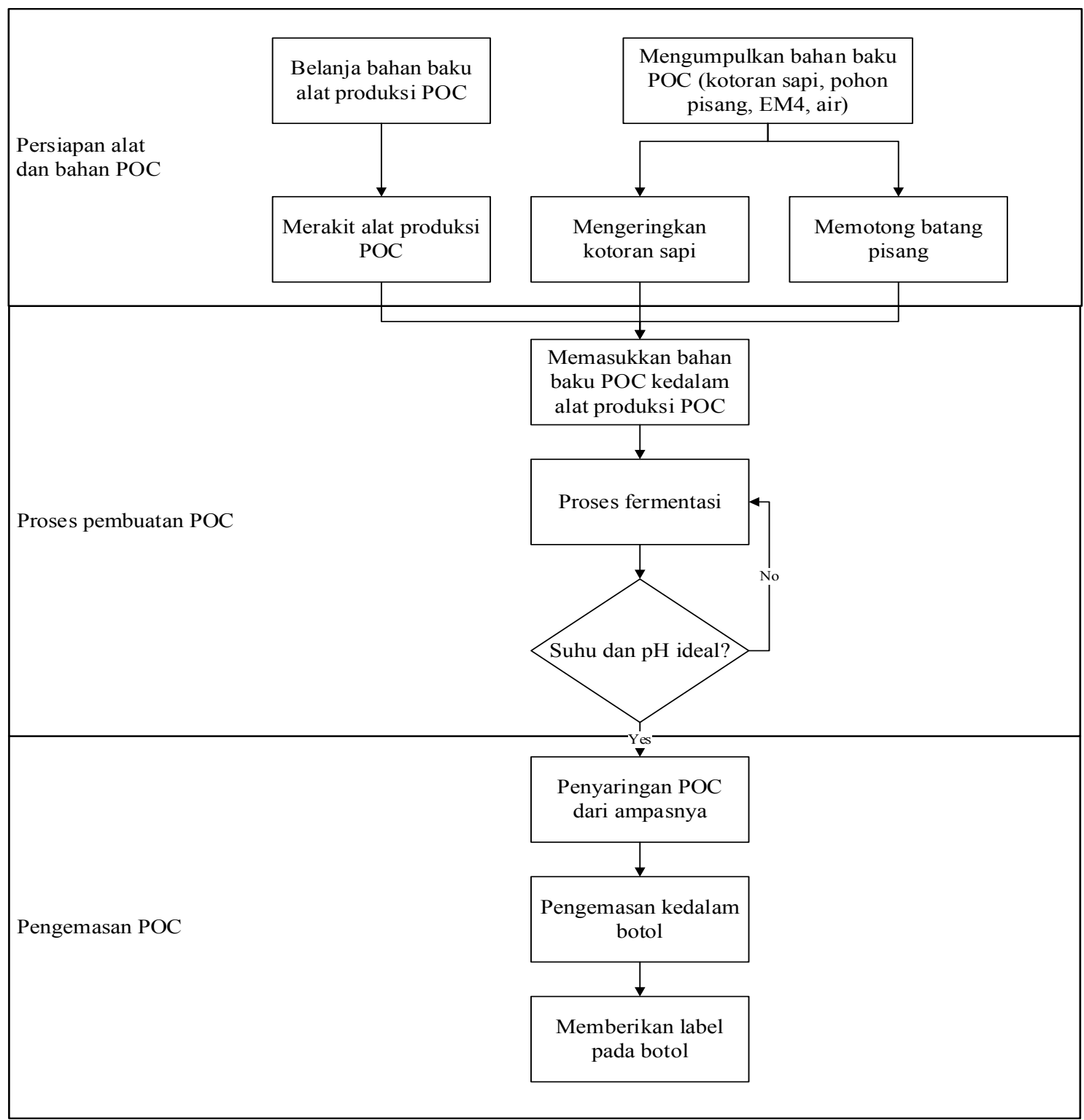

Gambar 2. Tahapan Pelaksanaan Kegiatan.

Tabel 1. Rincian Biaya Produksi POC ASARI.

\begin{tabular}{|c|c|}
\hline Bahan & Biaya \\
\hline Kotoran sapi & - \\
\hline Bonggol pisang & - \\
\hline Sereh & - \\
\hline 2 liter & Rp40.000 \\
\hline Molase 3 liter & Rp20.000 \\
\hline $\mathrm{H}_{2} \quad 1 \mathrm{btl}$ & Rp25.000 \\
\hline transportasi & Rp30.000 \\
\hline Botol $1 / 2$ liter $(4 \mathrm{rbx} 70)$ & Rp280.000 \\
\hline Stiker (1rbx70) & Rp70.000 \\
\hline Kardus (5rbx6) & Rp30.000 \\
\hline Total & Rp495.000 \\
\hline
\end{tabular}

Berdasarkan tabel 1, diperoleh total biaya produksi 70 botol dengan ukuran setengah liter yakni sebesar Rp495.000. Pada umumnya harga pasar untuk POC berukuran setengah liter sebesar Rp40.000 - Rp60.000 perbotol. Apabila perbotol dijual pada harga Rp35.000 maka akan dipeloleh pendapat kotor Rp2.450.000 untuk 70 botol ukuran setengah liter. Laba bersih dari produksi POC mencapai Rp1.955.000. Namun, sebelum tahap komersialisasi masih diperlukan uji kandungan unsur hara di laboratorium. Pada saat ini, kelompok karang taruna masih menggunkan pengujian langsung dengan beberapa sayuran pada gambar 4 . 


\section{HASIL DAN PEMBAHASAN}

Pelaksanaan program pengabdian masyarakat dilaksanakan pada bulan September sampai Desember 2020 di Dusun Malasan, Klaten, Jawa Tengah. Kegiatan pelatihan sebagai mentor sebaya dan disseminator diikuti sebanyak lima orang anggota karang taruna. Desiminasi produksi pupuk organik cair dilakukan melalui konsultasi via media komunikasi online oleh dosen Universitas Telkom. Hasil desiminasi produksi dan subsidi POC yang dilakukan selama tiga bulan dirincikan dalam tiga desain pelaksanaan sebagai berikut: desain produksi POC skala kecil, pengujian konsentrasi POC pada beberapa tanaman, dan desiminasi produk POC dilanjutkan ke tahapan subsidi POC kepada kelompok tani di Dusun Malasan. Pada kegiatan ini masih sampai pada tahap produksi skala kecil dan pengamatan empiris untuk menentukan konsentrasi yang tepat pada berbagai jenis tanaman. Tahapan selanjutnya, perlu dilakukan pengujian pada skala laboratorium dan produksi skala besar untuk sampai pada kegiatan komersialisasi produk

Tahap produksi POC skala kecil menggunakan teknik fermentasi bahan organik dari limbah pertanian di lingkungan Dusun Malasan. Bahan utama POC berupa kotoran sapi yang sudah dikeringkan, bonggol pisang, molasses, EM-4, dan air (Manis, Supriadi, and Said 2017). Kotoran sapi kering yang kaya akan unsur hara bermanfaat untuk meningkatkan unsur hara tempat persemaian bibit tanaman baik media tanah (Rahayu 2020) ataupun air. Penggunaan bonggol pisang yang kaya gizi (Mawaddah 2021), pati (Haloho 2021), dan mikroba pengurai bahan organik (Jumina 2020) dapat meningkatkan unsur hara dalam tanah. Penambahan Effective Microorganism-4 (EM4) yang merupakan bakteri pengurai, bermanfaat untuk pembusukan bahan organik (Prabandari 2020) sehingga waktu fermentasi dapat lebih singkat. Lebih lanjut, EM4 juga dapat meningkatkan jumlah dan jenis mikroorganisme yang ada di dalam tanah sehingga dapat meningkatkan kesehatan dan kuantitas produksi panen tanaman. Teknik pengomposan secara umum bertujuan untuk merangsang jumlah dan aktivitas mikroorganisme pengurai yang bertugas, mengubah bahan organik menjadi unsur yang dapat diserap oleh tanaman (Purbasari, Saputra, and Effendi 2021).

Alat produksi POC skala besar, memerlukan sebanyak 5 drum ukuran 200 liter. Alat ini dirancang memiliki saringan ampas besar pada bagian dalam drum. Keran air diletakkan pada bagian bawah drum untuk memudahkan pengeluaran POC ketika telah selesai difermentasikan. Gambar 3 (a) menunjukkan alat atau tempat fermentasi POC, (b) tutorial produksi POC dan (c) menunjukkan pengujian pada tanaman dapat dilihat pada video https:// www.youtube.com/watch?v=ysEQVk46300. Tutorial produksi POC dapat diakses melalui website berikut: https://www.youtube.com/ watch? $v=r 9 j a L 3$ Soib8\&t=142s.

Hasil utama dari produksi Pupuk Organik Cair (POC) berupa POC dengan kosentrasi yang tinggi. Sehingga untuk dapat digunakan harus ditambahkan air terlebih dahulu. Oleh karena itu, sangat penting menemukan konsentrasi POC yang tepat agar bisa diimplementasikan pada berbagai jenis tanaman. Pada tahap ini, tim karang taruna melakukan uji konsentrasi secara rinci pada tanaman padi seperti yang disajikan pada tabel 2 dan tabel 3. Tabel 2 menunjukkan pengujian konsentrasi POC terhadap tinggi tanaman padi. Tabel 3 menyajikan jumlah anakan padi pada berbagai konsentrasi POC pada 30 dan 60 hari setelah tanam.

Pemberian POC pada tanaman padi dilakukan dengan penyemprotan ke bagian atas tanaman seperti gambar 3 (c). Metode ini dapat meningkatkan laju penyerapan unsur hara dibandingkan dengan penyiraman POC pada bagian akar (Havlin et al., 2016). Oleh karena itu, pada penelitian ini juga menggunakan metode penyemprotan pada saat pengujian konsentrasi POC.

Tabel 2. Uji konsentrasi POC terhadap tinggi tanaman padi.

\begin{tabular}{ccc}
\hline \multirow{2}{*}{ Konsentrasi } & \multicolumn{2}{c}{ Tinggi Tanaman $(\mathrm{cm})$} \\
\cline { 2 - 3 } & $\begin{array}{c}\text { 30 Hari } \\
\text { Setelah Tanam }\end{array}$ & $\begin{array}{c}\text { 60 Hari } \\
\text { Setelah Tanam }\end{array}$ \\
\hline Kontrol & 47,2 & 84,2 \\
$0.20 \%$ & 49,1 & 89,8 \\
$0.40 \%$ & 50,6 & 91,6 \\
$0.60 \%$ & 52,1 & 91,8 \\
\hline
\end{tabular}




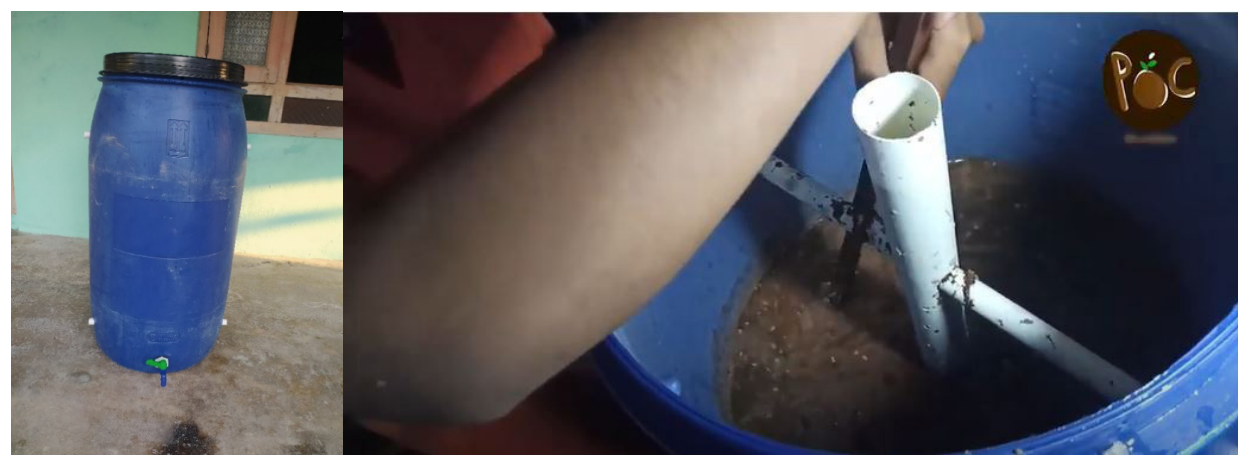

(a)
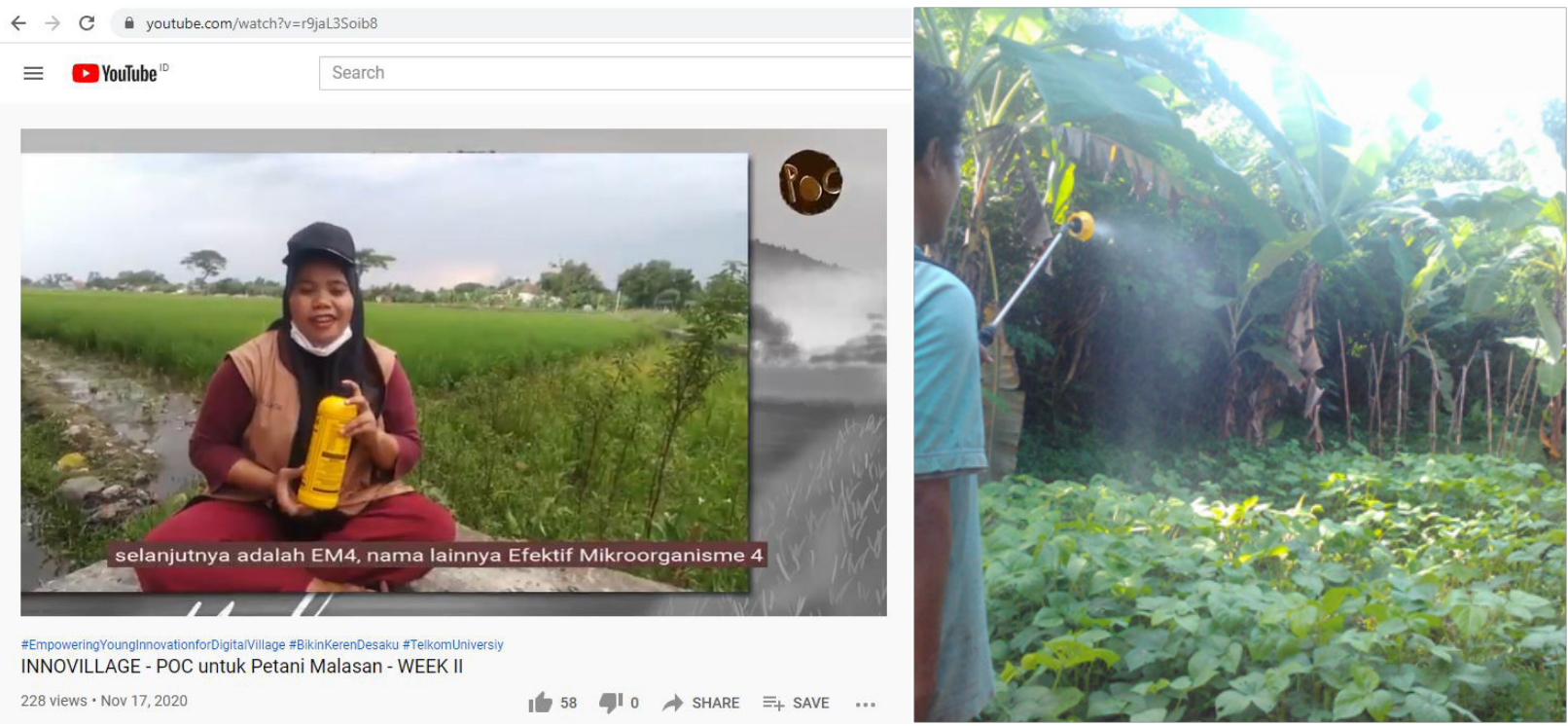

(b)

(c)

Gambar 3. Produksi POC (a) Drum sebagai Tempat Fermentasi POC, (b) Tutorial Produksi POC dan (c) Pengujian POC pada Tanaman di Media Tanah.

Beradasarkan hasil pengujian konsentrasi POC yang disajikan pada Tabel 1 menunjukkan bahwa, penyemprotan POC dengan konsentrasi 0,6\% mampu meningkatkan tinggi tanaman setelah 30 hari tanam. Sedangkan, penyemprotan $0,4 \%$ dan $0,6 \%$ POC pada tanaman berusia 60 hari terlihat hanya sedikit perbedaan tinggi.

Tabel 3. Jumlah Anakan Padi pada Berbagai Konsentrasi POC.

\begin{tabular}{|c|c|c|}
\hline Konsentrasi & \multicolumn{2}{|c|}{ Jumlah anakan } \\
\hline & $\begin{array}{c}\text { 30 Hari } \\
\text { Setelah Tanam }\end{array}$ & $\begin{array}{c}60 \text { Hari } \\
\text { Setelah Tanam }\end{array}$ \\
\hline Kontrol & 8 & 18 \\
\hline $0.20 \%$ & 10 & 26 \\
\hline $0.40 \%$ & 12 & 28 \\
\hline $0.60 \%$ & 13 & 32 \\
\hline
\end{tabular}

Pengamatan jumlah anakan yang disajikan pada tabel 3 menunjukkan bahwa, pemberian POC dengan konsentrasi 0,2 \% mampu meningkatkan jumlah anakan padi pada umur 30 dan 60 hari setelah tanam. Hal ini mengindikasikan bahwa, penyemprotan POC pada bagian tanaman padi dapat meningkatkan laju fotosintesis sehingga terjadi kenaikan jumlah anakan dibandingkan kondisi kontrol. Selanjutnya, pupuk diuji cobakan ke beberapa jenis tanaman seperti kacang hijau, tomat, cabe dengan berbagai konsentrasi untuk diamati pertumbuhannya seperti yang ditunjukkan pada Gambar 4. 
Aprillia, dkk - Pemberdayaan Karang Taruna Dusun Malasan ...

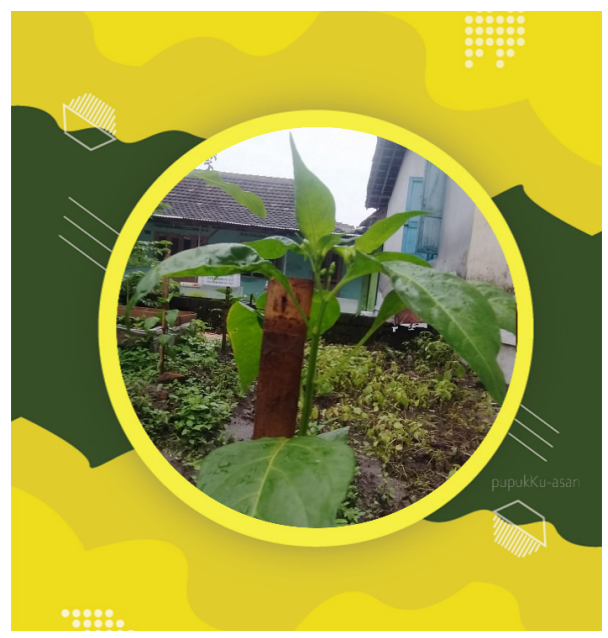

(a)

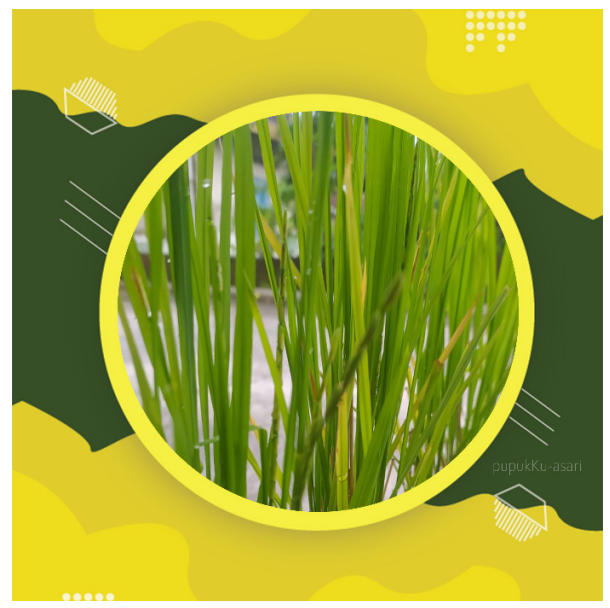

(c)

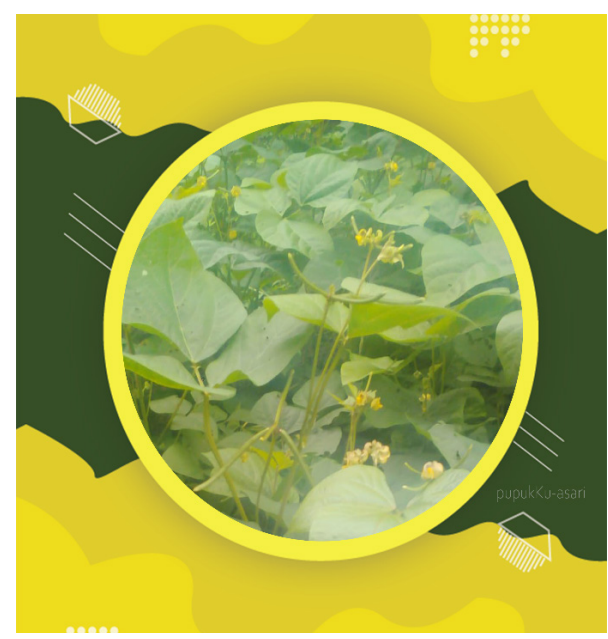

(b)

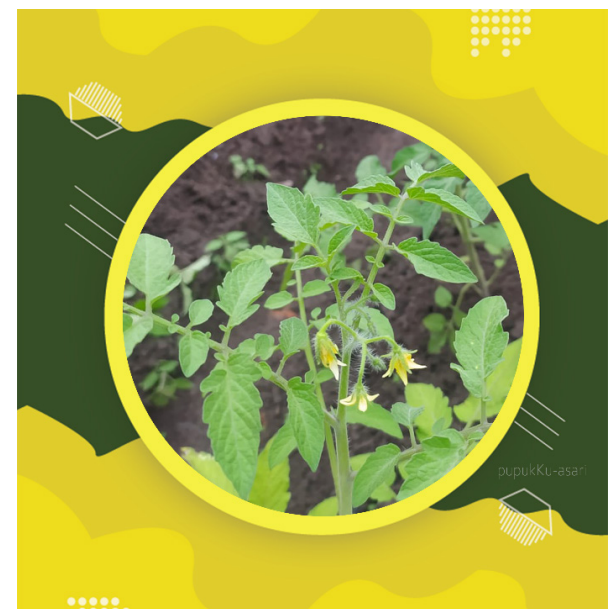

(d)

Gambar 4. Hasil Pengujian Konsentrasi POC pada Tanaman (a) Cabe, (b) Kacang Hijau, (c) Padi dan (d) tomat.

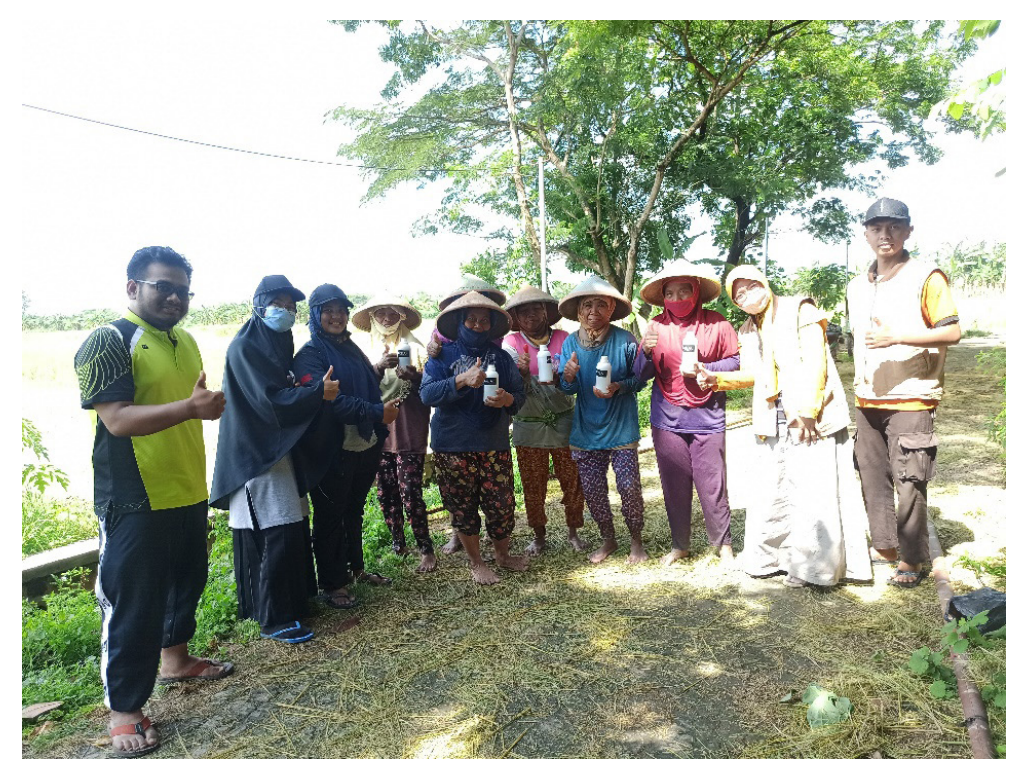

Gambar 5. Pembagian dan Sosialisasi POC. 
Desiminasi produk ke kelompok tani oleh karang taruna dilakukan dengan metode workshop seperti yang ditunjukkan pada Gambar 5. POC yang telah berhasil diujikan melalui beberapa tanaman pada Gambar 4 kemudian dibagikan kepada petani Dusun Malasan. Pada saat membagikan pupuk dilakukan sosialisasi terkait proses produksi dan tata cara penggunaan POC.

Tahapan pelatihan dan praktik produksi POC merupakan tujuan akhir dari kegiatan Pengabdian Kepada Masyarakat (PKM) yang didanai oleh Perusahaan Telkom Indonesia. Kegiatan ini memberikan peluang terbukannya wirausaha agribisnis untuk para pemuda karang taruna. Pada era pandemi Covid-19 ini pelatihan dilakukan secara online melalui WhatsApp. Pada pelatihan yang sama, pemuda pemudi karang taruna juga diajarkan pembuatan media pemasaran online dengan memanfaatkan media seperti Instagram dengan ID "ASARI" seperti yang ditunjukkan Gambar 6. Bentuk botol pada gambar 5 (a) merupakan kemasan POC dengan kapasitas setengah liter sedangkan pada gambar 6, botol berisikan satu liter POC.

Untuk mengukur perubahan pengetahuan yang terjadi pada karang tarunan terkait produksi dan pelatihan pemasaran produk maka tim Universitas Telkom telah melakukan evaluasi melalui kuis yang dikerjakan sebelum dan sesudah pelatihan seperti yang disajikan pada tabel 4 .

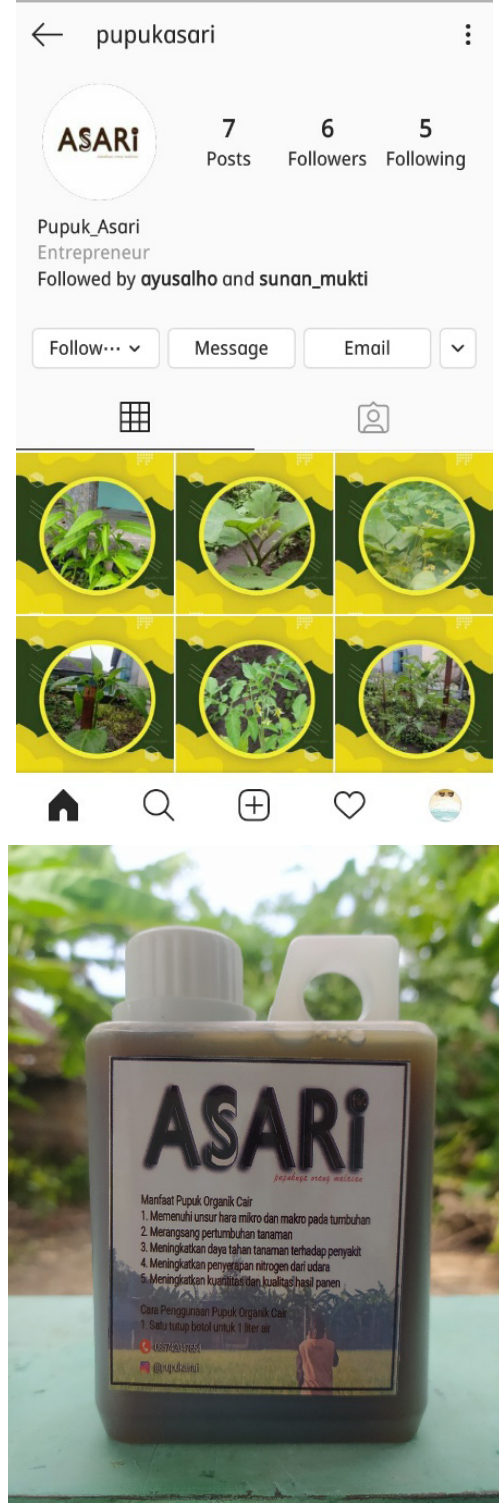

Gambar 6. Media Pemasaran Produk POC dan Gambar Produk POC dalam 1 Liter.

Tabel 4. Evaluasi Pengetahuan Karang Taruna Terkait Produksi dan Pemasaran POC.

\begin{tabular}{|c|c|c|c|c|}
\hline \multirow[t]{2}{*}{ Pengetahuan Produksi dan pemasaran POC } & \multicolumn{2}{|c|}{ Sebelum pelatihan } & \multicolumn{2}{|c|}{ Sesudah platihan } \\
\hline & Jumlah & Persentase & Jumlah & Persentase \\
\hline $\begin{array}{l}\text { Mengetahui bahan yang digunakan dalam } \\
\text { pembuatan POC }\end{array}$ & 39 & $95 \%$ & 41 & $100 \%$ \\
\hline $\begin{array}{l}\text { Mengetahui proses pembuatan POC namun } \\
\text { belum pernah membuat POC }\end{array}$ & 39 & $95 \%$ & 2 & $4,9 \%$ \\
\hline $\begin{array}{l}\text { Pernah membuat POC namun belum tahu cara } \\
\text { memasarkan }\end{array}$ & 38 & $93 \%$ & 3 & $7,3 \%$ \\
\hline Mengetahui media pemasaran produk & 40 & $98 \%$ & 41 & $100 \%$ \\
\hline
\end{tabular}


Berdasarkan tabel 4 dapat disimpulkan bahwa para anggota karang taruna di Dusun Malasan, mengetahui bahan yang digunakan untuk pembuatan POC dan media pemasaran produk. Akan tetapi, 95\% anggota karang taruna belum pernah produksi sendiri dan sebanyak 93\% belum tahu cara memasarkan produk. Setelah dilakukan pelatihan produksi dan pemasaran POC di karang taruna, Dusun Malasan lebih dari 85\% anggota karang taruna mampu mempraktikkan proses produksi dan pemasaran POC.

Pelaksanaan kegiatan PKM dievaluasi berdasarkan hasil kuesioner yang diisi oleh masyarakat sasar di Dusun Malasan. Kuesioner pada tabel 5 menunjukkan penilaian pada komponen pelakasanaan program PKM.

Evaluasi kegiatan PKM dalam kuesioner, meliputi evaluasi proses tutor sebaya dan evaluasi terkait aspek desiminasi dan pelatihan komersialisasi yang ditampilkan secara ringkas pada tabel 5. Masyarakat Dusun Malasan 83\% setuju bahwa PKM sesuai dengan tujuan program. 33\% masyarakat menyatakan bahwa waktu pelaksanaan program belum mencukupi kebutuhan. Hal ini dikarenakan pengujian unsur hara di laboratorium masih dalam antrean sehingga proses produksi skala besar dan komersialisasi belum terlaksana. Oleh karena itu, tim Universitas Telkom dan tim karang taruna sepakat untuk fokus pada pengujian empiris dan pemberian subsidi POC kepada kelompok tani sebagai program jangka pendek (3 sampai 6 bulan). Sedangkan, program jangka Panjang (bulan 7 sampai 12) akan dilakukan analisa hasil laboratorium, produksi skala besar, otomatisasi proses produksi POC, dan komersialisasi produk pada akun yang sudah dibuat pada saat pelatihan komersialisasi seperti yang ditunjukkan pada gambar 5 .

\section{SIMPULAN}

Kegiatan PKM ini berhasil mengeluarkan potensi alam di Dusun Malasan, Klaten, Jawa Tengah yang kaya akan limbah pertanian dan perkebunan. Program jangka pendek (September sampai Desember 2020) saat ini masih pada tahap produksi POC skala kecil, pemberian subsidi POC kepada kelompok tani dan pelatihan komersialisasi. Beradasarkan hasil pengujian konsentrasi POC terhadap tinggi tanaman padi menunjukkan bahwa, penyemprotan POC dengan konsentrasi $0,6 \%$ mampu meningkatkan tinggi tanaman setelah 30 hari tanam. Sedangkan, penyemprotan $0,4 \%$ dan 0, 6\% POC pada tanaman berusia 60 hari terlihat hanya sedikit perbedaan tinggi. Selain itu, pemberian POC dengan konsentrasi 0,2 \%

Tabel 5. Evaluasi Kegiatan Pengabdian Masyarakat

\begin{tabular}{|c|c|c|c|c|}
\hline \multirow{2}{*}{ Penilaian Terhadap Kegiatan } & \multicolumn{4}{|c|}{$\begin{array}{l}\text { Jumlah Masing-Masing Faktor yang } \\
\text { Dipentingkan }\end{array}$} \\
\hline & $\begin{array}{l}\text { Sangat Tidak } \\
\text { Setuju }\end{array}$ & $\begin{array}{l}\text { Tidak } \\
\text { Setuju }\end{array}$ & Setuju & $\begin{array}{l}\text { Sangat } \\
\text { Setuju }\end{array}$ \\
\hline Kegiatan PKM sudah sesuai tujuan. & 0 & 0 & 2 & 10 \\
\hline Kegiatan PKM sesuai kebutuhan di Dusun Malasan. & 0 & 0 & 3 & 9 \\
\hline $\begin{array}{l}\text { Durasi waktu kegiatan PKM sesuai dengan yang } \\
\text { dibutuhkan oleh kelompok tani dan karang taruna di } \\
\text { Dusun Malasan. }\end{array}$ & 0 & 4 & 5 & 3 \\
\hline $\begin{array}{l}\text { Dosen dan mahasiswa tanggap terhadap masalah } \\
\text { yang dihadapi selama kegiatan berlangsung. }\end{array}$ & 0 & 0 & 2 & 10 \\
\hline $\begin{array}{l}\text { Masyarakat di Dusun Malasan ingin melanjutkan } \\
\text { program di masa mendatang. }\end{array}$ & 0 & 0 & 2 & 10 \\
\hline Jumlah & 0 & 4 & 15 & 41 \\
\hline$\%$ (Jml masing-masing: total) & $0 \%$ & $6,7 \%$ & $25 \%$ & $68,3 \%$ \\
\hline Jumlah \% setuju+sangat setuju & \multicolumn{4}{|c|}{$100 \%$} \\
\hline
\end{tabular}


mampu meningkatkan jumlah anakan padi pada umur 30 dan 60 hari. Setelah dilakukan pelatihan produksi dan pemasaran POC di Karang taruna, Dusun Malasan lebih dari 85\% anggota karang taruna mampu mempraktikkan proses produksi dan pemasaran POC. Berdasarkan hasil evaluasi berbasis kuesioner, Masyarakat Dusun Malasan 83\% setuju bahwa PKM sesuai dengan tujuan program. 33\% masyarakat menyatakan bahwa waktu pelaksanaan program belum mencukupi kebutuhan.

\section{PERSANTUNAN}

Terima kasih kepada Perusahaan Telkom Indonesia melalui program pendanaan Innovilage ini, sehingga kegiatan program jangka pendek ini dapat memberikan subsidi pupuk organik cair (POC) kepada kelompok tani di Dusun Malasan. Terima kasih kepada rekan-rekan karang taruna di Dusun Malasan, Klaten yang sangat aktif belajar, mengajar, dan menyampaikan hasil desiminasi ke kelompok tani sehingga dapat membantu meningkatkan produksi pangan melalui penyedian pupuk.

\section{REFERENSI}

Fabiani, Verry Andre, Fajar Indah Puspita Sari, Nurhadini Nurhadini, Adisyahputra Adisyahputra, and Ristika Oktavia Asriza. (2020). Peningkatan Kualitas Pupuk Kompos dari Limbah Rumah Tangga Menggunakan Stimulator Em4 Pada Kelompok Swadaya Masyarakat Srimenanti Jaya Kabupaten Bangka, SELAPARANG Jurnal Pengabdian Masyarakat Berkemajuan, 4: 504-08.

Haloho, Alfianda Utama. (2021). 'Pengaruh Pemberian Kompos Ampas Tebu dan POC Limbah Buah Jambu Biji terhadap Pertumbuhan dan Produksi Jagung Manis (Zea Mays Saccherate Start), Universitas Medan Area.

Havlin, John L, Samuel L Tisdale, Werner L Nelson, and James D Beaton. (2016). Soil Fertility and Fertilizers (Pearson Education India).

Jumina, Cakrawati. (2020). Pengaruh Beberapa Bahan Baku terhadap Karakteristik Bio-Aktivator yang Dihasilkan dari Limbah Pertanian, Universitas_Muhammadiyah_Mataram.

Manis, Ince, Supriadi Supriadi, and Irwan Said. (2017). Pemanfaatan Limbah Kulit Pisang sebagai Pupuk Organik Cair dan Aplikasinya terhadap Pertumbuhan Tanaman Kangkung Darat (Ipomea Reptans Poir). Jurnal Akademika Kimia, 6: 219-26.

Mawaddah, Zahara. (2021). Pengaruh Campuran Konsentrasi Pupuk Organik Cair Bonggol Pisang (Musa Paradisiaca) dengan Unsur Hara Makro Nutrisi Hidroponik terhadap Pertumbuhan Tanaman Pakcoy (Brassica Rapa L.) Sistem NFT, UIN Sunan Gunung Djati Bandung.

Moko, Koko Widyat, Suwarto Suwarto, and Bekti Wahyu Utami. (2017). Perbedaan Persepsi Petani terhadap Program Kartu Tani di Kecamatan Kalijambe Kabupaten Sragen. Caraka Tani: Journal of Sustainable Agriculture, 32: 9-13.

Prabandari, Firly Diah. (2020). Pengaruh Urin Sapi sebagai Pupuk Organik Cair dengan Penambahan Em4 terhadap Pertumbuhan Tanaman Seledri (Apium graveolus L.) Dimanfaatkan sebagai Sumber Belajar Biologi, Universitas Muhammadiyah Malang.

Purbasari, Heppy, Ilham Rochad Saputra, and Mahardhika Yusack Effendi. (2021). Pendampingan dalam Pengelolaan Informasi POC Fermentasi Urine Kelinci, Jurnal Komunitas: Jurnal Pengabdian kepada Masyarakat, 3: 90-94.

Rahayu, Dewi. (2020).Pengaruh Pemberian Pupuk Kandang Kotoran Sapi pada Media Tanam Tanah, Pasir, dan Serbuk Kayu terhadap Pertumbuhan Tanaman Cabai Rawit (Capsicum Frutescens l.), UIN Sunan Ampel Surabaya.

Sirajuddin, Sitti Nurani, Siti Nurlaelah, Ilham Rasyid, Jamilah Mustabi, and Rosmawaty Rosmawaty. (2021). Proses Pembuatan Pupuk Organik dari Limbah Pertanian dan Limbah Sapi di Kelompok 
Aprillia, dkk - Pemberdayaan Karang Taruna Dusun Malasan ...

Tani Sipakainge, Kecamatan Barru, Kab. Barru. IGKOJEI: Jurnal Pengabdian Masyarakat, 2: 8-158-15.

Viery, Rinaldo, Syafridatati Syafridatati, and Wahyuni Ramadhani Deaf. (2020).Pertanggungjawaban Pidana terhadap Pelaku yang Memperjual Belikan Pupuk Bersubsidi, Universitas Bung Hatta. 